\title{
Promising teacher practices: students' views about their science learning
}

\author{
Azra Moeed1, Matthew Easterbrook ${ }^{2}$ \\ ${ }^{1}$ Faculty of Education, Victoria University of Wellington, Wellington, New Zealand \\ ${ }^{2}$ Science Department, Linwood College, Christchurch, New Zealand \\ For correspondence: azra.moeed@vuw.ac.nz
}

\begin{abstract}
Internationally, conceptual and procedural understanding, understanding the Nature of Science, and scientific literacy are considered worthy goals of school science education in modern times. The empirical study presented here reports on promising teacher practices that in the students' views afford learning opportunities and support their science learning. The research is an illuminating case study of learning science in a large urban coeducational high school in New Zealand. The participants were one science teacher and his class of 28 students (age 13/14 years). Data were collected through classroom observations (63 lessons), a questionnaire, and interviews with all students in groups of 4/5. Illuminating examples of the six most promising practices and student views about how these practices helped them to learn science are presented. Practical work was common in the study class and was analysed for its effectiveness. The research was underpinned by a constructivist theory of learning.
\end{abstract}

Keywords: Science teaching strategies, secondary science learning, secondary science teaching, science learning strategies.

\section{Introduction}

Learning science in school involves developing conceptual and procedural understanding as well as understanding the Nature of Science (Author 2015; Lederman \&Abell, 2014; Millar, 2012;Schwartz, Lederman, \& Crawford, 2004). There is considerable agreement amongst researchers that all three aspects are essential for learning science in secondary school. Teaching of all three is a mandatory requirement of The New Zealand Curriculum (Ministry of Education, 2007). The concerns, doubts, and relative importance of each aspect in relation to students' learning are debated in literature (Abrahams \&Millar,2008). Internationally, the current focus of science education for this millennium is for all students to be scientifically literate citizens (Hodson, 2014;McFarlane, 2013). The belief is that such citizens will be able to make informed decisions about socio-scientific developments and rapidly growing new technologies that are likely to impact on their everyday lives. A further focus has been to make science "authentic" for the learner which has led to an analysis of scientific thinking from a psychological cognitive perspective (Zimmerman \& Croker, 2014). Gunstone, Fensham, and Gunstone (2013) provide a critical perspective of science learning through taking a constructivist approach.

Loughran and Berry (2011) argue that too often science teaching is in the form of delivering facts and information and assert that good science teaching ought to support students to become active and responsible learners. Their case study research has shown that when teachers gave the students opportunities to make choices and had high expectations of learning, they found that their students became responsible learners. Loughran and Berryman further contend that teaching approaches that work are often enthusiastically taken up by other teachers but why these approaches work is rarely considered, and they would like teachers to involve students in a decision making process regarding what approach works best for the students they are teaching. 


\section{Theoretical Perspectives}

Practical work, a pedagogical approach. Practical work is a much used approach to science teaching and could be argued to be only second to a transmission approach. Yet, research suggests that learning through practical work is not as effective as it could be and this has not changed for nearly two decades (Abrahams \& Millar, 2008; Hodson, 1990). Both Hodson and Millar offer suggestions about how learning through practical work can be enhanced. Hodson (2014) argues that effective pedagogy takes account of: what needs to be learnt; what knowledge, understandings and previous experiences students have; what resources are available; and teacher expertise. More specifically, Hodson asserts that "practical work for concept acquisition must work, work well and be seen by students to work well" (p. 7). For acquisition of conceptual knowledge he argues it needs to be presented as a wellrehearsed theatre act that demonstrates the phenomenon the teachers want students to learn. Practical work for developing procedural understanding needs to include the following four phases: planning; performance or data gathering; reflection including analysis, interpretation, and drawing of evidencebased conclusions; and reporting and communication. These four phases can help in the development of an understanding of the nature of scientific investigation. Hodson maintains that learning to do science is best done alongside an experienced practitioner and suggests modelling, guided practice, followed by application. For doing science students need to do it by themselves for themselves and ought to have complete control of the process. Learning about socio-scientific issues can only be done through providing opportunities for raising awareness of current issues, students learning to critique articles in the social media, videos, news items and looking at the robustness of the evidence presented. These ideas about the multiple approaches to teaching are relevant to the study as the study class teacher used a wide range of pedagogical approaches.

Frameworks. Millar $(2004,2012)$ argues that when using practical work as a teaching strategy, teachers need to be cognisant of the role of practical work in developing students' science ideas, and further that students need to manipulate both objects and ideas and the practical work ought to be used to help students to make links between the domain of objects and ideas (Figure 1). Millar (2004) asserts that it is highly unlikely that students will develop conceptual understanding through participating in a single investigation and reminds that discussion that follows practical work is critical in developing conceptual understanding.

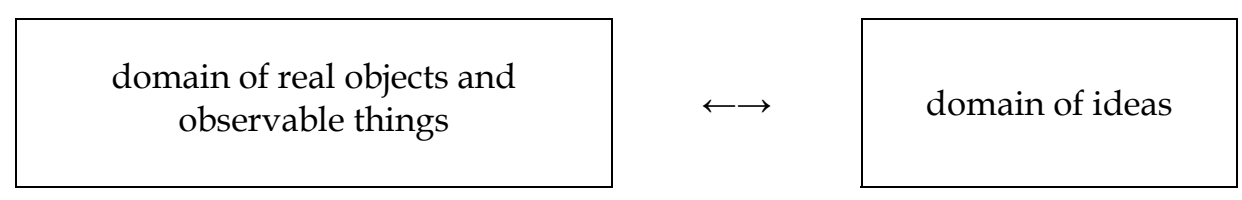

Figure 1.Practical Work: Linking Two Domains of Knowledge (Millar, 2004, p. 8)

Millar (2010) provides a useful guide to planning, presenting and reflecting on effectiveness of practical work. Abrahams and Millar (2008) theorise that for learning to be effective the teacher must be clear about what they intend the students to do as well as what they want the students to learn. The purpose of intended learning needs to be shared with the students. They suggest a framework for this analysis. Practical work was a preferred pedagogical approach for the teacher and this framework was used in analysing the practical work in this research (Figure 2). 


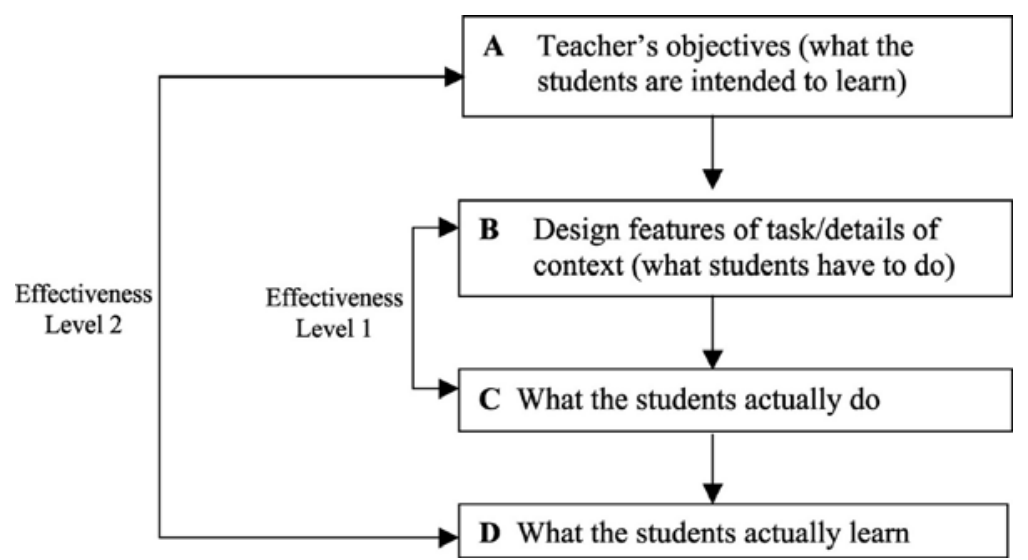

Figure 2. Model of the Process of Design and Evaluation of a Practical Task (Abrahams \& Millar, 2008, p. 1947)

Learning strategies. Learning strategies are behaviours and thoughts that help learners consider, retain and store multiple forms of knowledge. Cognitive learning strategies allow learners to manipulate information and are task specific, for example, taking notes and asking questions. By contrast, meta cognitive learning strategies require planning, monitoring, and evaluation (Selçuk, Sahin, \& Acikgoz, 2009). Selçuk et al. describe several categories of learning strategies that broadly fall into: rehearsal strategies (e.g., repetition, copying); elaboration strategies (mental images, pairing, paraphrasing, summarising); organisational strategies; grouping, ordering, monitoring strategies (e.g., checking for comprehension); and motivational strategies (creating, monitoring and controlling an effective learning environment).

The purpose of the research was to investigate teaching approaches taken by an experienced science teacher to find out how students believed these teaching approaches support student learning. The research reported here set out to answer the following research question:

\section{Research question:}

What teaching strategies support Year 10 students science learning and why?

\section{Research Design:}

To answer this research question a qualitative case study was considered the best approach to gain a deep understanding of science learning. Case studies provide "thick rich description of the phenomenon under study" (Stake, 1995, p. 42) and when used with an inductive approach to data analysis, as was applied in this study, "generalisations, concepts, or hypotheses emerge from an examination of the data grounded in the context itself" (Merriam, 1998, p. 13). The intention was to find out students' views about science teaching strategies that they believe support their learning. Therefore, the participating teacher was purposefully selected. He is recognised as an excellent teacher who has enhanced his practice through action research over the past ten years. The intention was to gain an insight into students' science learning in his year 10 mainstream class. During the data collection period three topics were taught: plant reproduction, animal reproduction, and electricity. In the first half of the academic year, 63 science lessons were observed (4 hour-long lessons each week), students were asked to complete a questionnaire about their science learning and space was provided for them to list what they did in their science class that helped them to learn. In the last week of data collection, students were interviewed in small groups. Practical work was analysed using Abrahams and Millar's(2008) framework. Observation, questionnaire and interview data were triangulated to have confidence in the findings. 


\section{Results}

During the observations it was noteworthy that students were purposefully engaged in the lessons most of the time. There was evidence of mutual respect and positive professional relationships between the students and the teacher. The teacher had effective strategies in place for gaining attention- he had set routines for the start and end of lesson, and collection and returning of resources was evident. According to the observation notes, there was only one occasion when the teacher took a student outside the class to talk to him about inappropriate behaviour. Analysis of task engagement data shows that students were on task on average for approximately $85-90 \%$ of class time.

Students identified 14 activities that in their view helped them to learn science. Of these the six activities selected by 20 or more students in the class of 28 are listed in Table 1.

Table 1: Promising Learning Strategies that Best Supported Student Learning

\begin{tabular}{lcl}
\hline Promising practices & $\begin{array}{l}\text { Useful/most } \\
\text { useful n=28) }\end{array}$ & Salient feature \\
\hline Sparklers & 28 & $\begin{array}{l}\text { Getting started/ working with } \\
\text { peers }\end{array}$ \\
\hline $\begin{array}{l}\text { Learning game “I have, } \\
\text { who has" }\end{array}$ & 28 & Competition/careful listening \\
\hline Practical work & 26 & Choice/fun/working with peers \\
\hline Three level readings & 24 & Choice/support \\
\hline Watching videos & 24 & $\begin{array}{l}\text { Not doing worksheets/ having } \\
\text { one question to think about. }\end{array}$ \\
\hline Blog entries & 20 & $\begin{array}{l}\text { Sort of homework, more like } \\
\text { asking each other }\end{array}$ \\
\hline
\end{tabular}

During the interviews students talked about these strategies which they saw as promising practices "This is what Mr does that helps us to learn" (Ben).

At the start of most lessons, the teacher had the learning intentions for the lesson and the success criteria written on the board and for every lesson he shared these with the class. Each lesson ended with a reflection where they revisited the success criteria. All students had listed these as most useful. For example, Dana said. "we know exactly what we are going to do, when we have a double period, he tells us what we will do in the first hour and in the second hour". Students liked the reflection, and all agreed it was very useful. Richard said, "You leave the class knowing what you have learnt" and Tim added, "the teacher knows what we have not learnt so we can do it next time."

Sparklers are booklets for each topic, a collection of crossword puzzles, pair matching tasks, word finds, and diagrams to label or complete. When students arrive in class, the booklets are on their desks and they start working on them. They are expected to complete these by the end of the topic. The most common remarks during interviews were that they enjoyed doing the tasks $(\mathrm{n}=24)$ : "the best thing was being able to help each other" $(n=20)$. Sparklers were used in all observed lessons. The tasks were achievable by most and reinforced what was being learnt.

Learning game was used as a vocabulary learning activity. Each student was given a little card with a definition and a word on it. So the first person would, for example, say "I have genes, who has the alternative forms of genes?" The person who has allele, would respond, I have Allele, who has...? And so on. Students said they liked it because it helped them to learn the vocabulary, and it was fun. The game had an element of competition in that the teacher would time them as to how long it took, and their goal was to beat their previous time.

Practical work took place in 59 out of 63 observed lessons. Sometimes it was an opportunity to plan and carry out an investigation $(n=7)$, or an opportunity to learn a skill, or to Predict, Explain, Observe, 
Explain (PEOE). Students had plenty of opportunity to explore, for example, a number of flowers to look for parts that all flowers had. They made paper models of plant and animal cells. One negative comment from Sarah was that when they were setting up circuits, the teacher gave them instructions on exactly how to do it as a series of steps. She added, "I, would have liked to figure it out myself". Others in the focus group nodded in agreement.

Practical work was done in 59 lessons and in 42 of these practical activities the intended learning was communicated to the students. However, on 12 occasions learning intentions needed clarification after they had carried out the practical work. At all other times the intended learning was shared before the practical activity, For example, when students investigated flowers the learning intentions shared were:

1. We are going to dissect a fuchsia flower and look at all the parts

2. We will think about why a flower has these parts.

3. We will make biological drawings of these parts.

4. We will discuss why the flowers may be the same or different.

Seven investigations were carried out by the students. These were analysed using Assessment of effectiveness framework (Millar, 2010). See Appendix 1.

Table 2: An Example of the Analysis of Effectiveness of Practical Work Using the Millar (2010) Framework

\begin{tabular}{lc}
\hline \multicolumn{1}{c}{ Learning intention } & Level of Effectiveness \\
\hline We are going to dissect a fuchsia flower and look & Effectiveness level1 \\
at all the parts & \\
Evidence: All able to dissect flowers and identify \\
part on the given diagram.
\end{tabular}

We will think about why a flower has these parts.

Effectiveness level 2

Evidence:

Students discussed in groups and summarised

their reasons on paper at the end of lesson $(n=28)$

Students able to recall this at the start of the next

lesson through a written quiz $(\mathrm{n}=25$, only 27

present on the day).

We will make biological drawings of these parts.

Evidence:

Effectiveness level1

Students able to draw the diagram of the flower

they had dissected and label main parts

(drawings show a range, but all attempted and

completed the task).

Each of us will look at three or more other

Effectiveness level1

flowers and identify if these flowers have the

same parts.

Evidence:

Most able to identify parts individually. Evidence

of peer support when one could not find a

particular part.

We will discuss why they may be the same or different.

1 Students discussed possible reasons for difference between their flowers.

2 Teacher-led discussion.

3 Students drew individually, wrote the difference between their flower and the 
common flower used by the whole class.

Evidence:

All completed this task in their books.

23 provided plausible reasons for the difference.

And four did not appear to have got the idea.

Three levels of reading -when the teacher wanted them to read something, often he put out three readings and students could choose one of the three. The advanced level had more text and was for those who were the most confident readers, level two had a balance between moresimple textthat was about a page long with some pictures, and the third level had simple text and more visuals including pictures, graphs and diagrams. This was done six times during the observed lessons but the students said they found the choice and support from each other useful. The general practice was for the students to read in silence and if they did not understand a word, they got up and wrote it on the whiteboard. As students finished their reading and if they could explain what the word on the board meant, they would write the meaning on the board next to the word. On most occasions someone in the class was able to clarify a word that someone else did not know. At the end, the teacher would talk about the main messages from the readings and sort out any words that no-one understood. Students liked the choice of readings but often a few would pick the easiest ones.

Videos were used in approximately one out of three lessons. They were brief and the students said they liked it when they were given a question on the board, to think about rather than having to complete a worksheet as they watched. They said they liked things they had to think about; for example Rose said, "when you are asked to think about how wind pollination is the same as or different to insect pollination, then I have to really think about what the teacher wants me to see while watching the video."

Blogs were encouraged as homework tasks and most students like these. Tim said, "You can just ask others if you get stuck". Students also said that this was a "way better" way of doing homework.

Students found some learning strategies not as helpful as those listed in Table 1. It is noteworthy that the less attractive strategies were still seen as useful, and as one student put it, "they just were not as enjoyable."

Table 3: Less Attractive Strategies

\begin{tabular}{|l|c|l|}
\hline \multicolumn{1}{|c|}{$\begin{array}{c}\text { Less attractive } \\
\text { practices }\end{array}$} & $\begin{array}{c}\text { Less useful } \\
(\mathrm{n}=28)\end{array}$ & \multicolumn{1}{|c|}{ Salient feature } \\
\hline Flip shutes & 13 & Helpful in learning meanings of words. \\
\hline Pair matching cards & 12 & $\begin{array}{l}\text { Useful in topics needing a lot of } \\
\text { vocabulary. }\end{array}$ \\
\hline Concept maps & 11 & $\begin{array}{l}\text { Linking new ideas to the original map } \\
\text { each week. }\end{array}$ \\
\hline Caring for plants & 11 & Routine to remember to water plants. \\
\hline Writing & 10 & Putting notes into books. \\
\hline Worksheets & 10 & Reinforcing the content. \\
\hline
\end{tabular}

\section{Discussion and Conclusion}

As stated earlier, this study has only reported one data set from the study. Observation notes showed many instances when students had understood science ideas, developed skills and were developing an understanding about the nature of science (Hodson, 2014). There was a strong focus on ascertaining what had been learnt and identifying the next learning steps (Gunstone et al., 2013). Abrahams and Millar (2008) argue that it is not sufficient to tell students what to do but important to say what the intended learning is for practical work to be effective. There was strong evidence of 
sharing the learning intention not onlyabout what the students were going to do but also what they were going to learn by doing it. There was strong evidence of this in the class and students said it helped them to learn. Students were learning the vast vocabulary that goes with learning science, they were learning practical skills and developing the understanding that science is evidence based. Their readings challenged them to think and figure out the argument being made in an article and they were given the time to discuss why they aligned themselves with a particular view. The teacher had a sound understanding of the nature of science investigation and gave the students the opportunity to experience the many ways in which scientists investigate (Author, 2010; Ministry of Education, 2007). The start of each lesson with the sparklers was the teacher's way of building in formative assessment; it encouraged both peer and teacher feedback on their progress (Black \&Wiliam, 2009).

There was evidence that students were being metacognitive about their learning (Selçuk et al., 2009). Learning strategies were a fun way of helping students to learn through repetition, whereas videos were used to reinforce learning and to highlight particular content. Practical work was used for skill development but also for conceptual understanding. Models and thoughtful activities such as threelevel readings were used for extension work to develop the skills of being critical and to enhance scientific literacy (Hodson, 2014). Lesson structure provided many opportunities for teacher-student and student-student interaction; the social constructivist theory of learning was seen in practice (Baviskar, Hartle, \& Whiney, 2008; Windschitl, 2002). The lessons showed that the teacher knew all his students and their learning needs well. The promising teacher practices ensured that the students learnt with and from each other and were confident about their science learning. It was also evident that the teacher cared about his students and cared about their learning, and the students were aware of it (Averill, 2012).

The limitation of the study is that it was carried out in one school and with 28 students and their teacher so the findings cannot be generalised. However, when there is research evidence that suggests that practical work is not as effective as it could be, it is promising to see that it is achievable as was the case in this research.

\section{Acknowledgements}

The authors would like to thank Dr Abdul Moeed and Susan Kaiser for commenting on drafts and editing of the manuscript. The authors would also like to thank the teacher and students without whom this research could not have taken place.

\section{References}

Abrahams, I., \&Millar, R. (2008). Does practical work really work? A study of the effectiveness of practical work as a teaching and learning method in school science. International Journal of Science Education, 30(14), 19451969.doi.org/10.1080/09500690701749305

Author (2015). Springer Singapore.

Author (2014). International Journal of Professional Development.

Averill, R. (2012). Caring teaching practices in multiethnic mathematics classrooms: Attending to health and well-being. Mathematics Education Research Journal, 24(2), 105-128.doi.org/10.1007/s13394-011-0028-x

Baviskar, S. N., Hartle, R. T.,\& Whiney, T. (2008). Essential criteria to characterize constructivist teaching: Derived from a review of literature and applied to five constructivist-teaching method articles. International Journal of Science Education, 1, 1-10. doi.org/10.1080/09500690701731121

Black, P., \&Wiliam, D. (2009).Developing the theory of formative assessment.Educational Assessment, Evaluation and Accountability, 21(1), 5-31.doi.org/10.4135/9781446250808.n13

Gunstone, P. J. F. R. F., Fensham, P. J., \&Gunstone, R. F. (2013). The content of science: A constructivist approach to its teaching and learning. New York: Routledge.

Hodson, D. (2014). Learning science, learning about science, doing science: Different goals demand different learning methods. International Journal of Science Education, 1-20.doi.org/10.1080/09500693.2014.899722

Lederman, N. G., \&Abell, S. K. (Eds.). (2014). Handbook of research in science education (Vol. 2). NetherlandsRoutledge.

Loughran, J., \& Berry, A. (2011). Making a case for improving practice: What can be learned about high-quality science teaching from teacher-produced cases?In Names of Editors (Eds.), Theprofessional knowledge base of science teaching(pp. 6581). Netherlands: Springer.

McFarlane, D. A. (2013). Understanding the challenges of science education in the 21st century: New opportunities for scientific literacy. International Letters of Social and Humanistic Sciences, 4, 35-44.

Merriam, S. B. (1998). Qualitative research and case study applications in education. San Francisco: Jossey-Bass.

Millar, R. (2004). The role of practical work in the teaching and learning of science. Paper presented for the meeting of high school science laboratories: Role and vision. Washington, DC: National Academy of Sciences. 
Millar, R. (2010). Analysing practical science activities to assess and improve their effectiveness. The Association of Science Education. Retrieved from

http://www.york.ac.uk/media/educationalstudies/documents/research/Analysing\%20practical\%20activities.pdf

Millar, R. (Ed.). (2012). Doingscience (RLE Edu O): Images of science in science education. New York:Routledge.

Ministry of Education. (2007). The New Zealand curriculum. Wellington: Learning Media.

Osborne, J. (2014). Teaching scientific practices: Meeting the challenge of change. Journal of Science Teacher Education, 25(2), 177-196.doi.org/10.1007/s10972-014-9384-1

Selçuk, G.S., Sahin, M., \&Acikgoz, K. U. (2009). The effects of learning strategy instruction on achievement motivation in a physics course. Research in Science Education,4(1), 39-62. doi:10.1007/s11165-009-9145-x

Stake, R. E. (1995). The art of case study. Thousand Oaks: Sage.

Windschitl, M. (2002). Framing constructivism in practice as negotiations of dilemmas: An analysis of the conceptual, pedagogical, cultural and political challenges facing teachers.Review of Educational Research, 72(2), 131-175. doi.org/10.3102/00346543072002131

Zimmerman, C., \& Croker, S. (2014). A prospective cognition analysis of scientific thinking and the implications for teaching and learning science. Journal of Cognitive Education and Psychology, 13(2), 245-257.doi.org/10.1891/19458959.13.2.245 


\section{Appendix}

Appendix 1 Framework used for analysing science investigation

Assessment of effectiveness when used

A Effectiveness at level (1)

Key question: Did students do what they were intended to do, and see what they were intended to see?

\begin{tabular}{llll}
\hline \multicolumn{1}{l}{} & $\begin{array}{l}\text { Mainly } \\
\text { yes }\end{array}$ & $\begin{array}{l}\text { Mainly } \\
\text { no }\end{array}$ & $\begin{array}{l}\text { Not } \\
\text { applicable }\end{array}$ \\
\hline 1 & Did students know how to use the equipment involved? \\
& $\begin{array}{l}\text { Were students able to set up the apparatus, and handle } \\
\text { the materials involved, correctly and safely? }\end{array}$ \\
\hline 3 & $\begin{array}{l}\text { Were students able to use the apparatus with sufficient } \\
\text { precision to make the necessary observations or } \\
\text { measurements? }\end{array}$ \\
\hline 4 & $\begin{array}{l}\text { Were students able to carry out any routine procedures } \\
\text { involved? }\end{array}$ \\
\hline 5 & $\begin{array}{l}\text { Were students able to follow any oral or written } \\
\text { instructions given? }\end{array}$ \\
\hline 6 & $\begin{array}{l}\text { Did students observe the outcome(s) or effect(s) you } \\
\text { wanted them to see? }\end{array}$ \\
\hline 7 & $\begin{array}{l}\text { Could students explain the purpose of the activity if } \\
\text { asked? (what they were doing it for) }\end{array}$ \\
\hline 8 & $\begin{array}{l}\text { Did students talk about the activity using the scientific } \\
\text { terms and ideas you would have wished them to use? }\end{array}$ \\
\hline
\end{tabular}

B Effectiveness at level (2)

Key question: Did students learn what they were intended to learn?

Most Some Few

$1 \quad$ How many students could recall what they did, and the main features of what they observed?

\begin{tabular}{lllll}
\hline Summarise the evidence for your answer above: & & \\
\hline 2 & $\begin{array}{l}\text { How many students have a better understanding of the ideas } \\
\text { the activity was intended to help them understand? }\end{array}$ & Most Some $\quad$ Few \\
\hline Summarise the evidence for your answer above:
\end{tabular}

Summarise the evidence for your answer above: 